\title{
Effect of Fasting on the Toxicity and Serum Concentration of Aminopyrine in Rats ${ }^{1}$
}

\author{
Herbert H. Cornish, A. B. Morrison, ${ }^{2}$ AND John M. Nelson \\ Department of Industrial Health, School of Public Health, \\ The University of Michigan, Ann Arbor, Michigan 48104
}

Received August 27, 1969

\begin{abstract}
Effect of Fasting on the Toxicity and Serum Concentration of Aminopyrine in Rats. Cornish, Herbert H., Morrison, A. B., and Nelson, JoHn M. (1970). Toxicol. Appl. Pharmacol. 17, 217-222. The acute oral toxicity of aminopyrine is considcrably greater in the fasted rat than in the fed rat. Acute toxicity by the ip route was comparable in these two groups of animals. Serum aminopyrine concentrations in the fasted rat reached maximum values within $5 \mathrm{~min}$ after oral dosing compared with approximately $15 \mathrm{~min}$ after dosing in the fed (ad libitum) animals. Maximum serum aminopyrine concentrations in the fasted rats were more than double those of the fed animals, thus accounting for the increased acute toxicity of this compound in fasted animals. These data not only indicate the importance of serum concentrations in toxicity studies, but also emphasize the necessity for consideration of the short-term nutritional status of the animals used in toxicologic investigations.
\end{abstract}

There are reports in the literature which demonstrate that fasting inhibits $\mathrm{N}$-demethylation in the rat liver microsomal enzyme system. After $16 \mathrm{hr}$ of fasting this activity was reported to be essentially zero (Roth and Bukovsky, 1961). If the metabolic fate of compounds that are metabolized by the microsomal enzyme systems can be altered by such a short period of fasting, then the short-term nutritional status of the animal assumes a most important role in toxicity testing as well as in studies of the metabolic fate of such compounds. Additionally, since a $24-\mathrm{hr}$ fasting period is not unusual in many clinical situations, such findings would assume an important role in drug therapy. A previous report from this laboratory (Cornish and Ryan, 1965) illustrated marked changes in benzene metabolism in fed and fasted rats. In the present study, the effect of fasting on aminopyrine toxicity was investigated.

Aminopyrine was selected for this study because its metabolic fate is well documented in a number of species. Brodie and Axelrod (1950) report that 4-aminoantipyrine, acetylaminoantipyrine, and hydroxyantipyrine are the major metabolites of aminopyrine in man. Banerjee et al. (1967) recently reported on the metabolism and excretion of aminopyrine in normal lactating dairy cattle. As percent of the original dose, the

\footnotetext{
${ }^{1}$ Supported by U.S. Public Health Service Grant No. GM-15269 from the National Institute of General Medical Sciences.

${ }^{2}$ On leave from Food \& Drug Research Laboratories, Department of National Health \& Welfare, Ottawa, Canada.
} 
following values were found in the urine: aminopyrine, 32.4\%; 4-aminoantipyrine, $9.2 \%$; acetylaminoantipyrine, $24.5 \%$; and 4-hydroxyantipyrine, $0.57 \%$. The conversion of aminopyrine to 4-aminoantipyrine involves $\mathrm{N}$-demethylating activity which is present in microsomal enzyme systems. The liver of fasted rats has been shown to have greatly reduced $\mathrm{N}$-demethylating activity (Dixon et al., 1960). Thus the present study was conducted to determine the effect of fasting on the oral toxicity of aminopyrine and on the rate of its metabolism in vivo.

\section{METHODS}

Groups of 10 male Sprague-Dawley rats (Spartan strain) fed ad libitum were given geometrically graded dosages of aminopyrine. LD50 values were calculated by the computer program of Berkson (1944). Fed animals received commercial rat chow ad libitum. Other groups of rats were fasted for $24 \mathrm{hr}$ before receiving the same oral doses. Water was allowed ad libitum to all groups.

The LD50 values were reevaluated by the ip route to determine the role of fasting on the rate of aminopyrine absorption from the gastrointestinal tract. To study possible effects of metabolic differences in these animals, ip studies included groups of rats injected with $\beta$-diethylaminoethyldiphenylpropylacetate hydrochloride (SKF-525-A $75 \mathrm{mg} / \mathrm{kg}$ ) $45 \mathrm{~min}$ prior to dosing with aminopyrine. SKF-525-A has been shown to inhibit at least some aspects of the microsomal drug metabolizing enzyme system (Axelrod et al., 1954).

Serum concentrations of aminopyrine and its major metabolite, 4-aminoantipyrine, were determined by the colorimetric method of Brodie and Axelrod (1950). For studies of serum concentrations, aminopyrine was given either po or ip at a dose of $200 \mathrm{mg} / \mathrm{kg}$. Six animals were sacrificed at varying time intervals up to $1 \mathrm{hr}$ after dosing.

\section{RESULTS}

All animals that died did so within a 24-hr period after dosing. Surviving animals were maintained for 14 days to check on latent effects. The oral and ip 14-day LD50 values are given in Tables 1 and 2 . In fed animals, the LD50 for aminopyrine was 3044 (2641-3508) $\mathrm{mg} / \mathrm{kg}$ compared with $1576(1252-1984) \mathrm{mg} / \mathrm{kg}$ for fasted rats. By the ip route, the LD50 was 251 and $261 \mathrm{mg} / \mathrm{kg}$ in fed and fasted animals respectively. In fed animals, pretreatment with SKF-525-A did not dramatically influence the ip LD50 (186 $\mathrm{mg} / \mathrm{kg}$ versus $251 \mathrm{mg} / \mathrm{kg}$ ). Nevertheless, the range of doses causing death was much greater in the animals given SKF-525-A and $200 \mathrm{mg} / \mathrm{kg}$ of aminopyrine whereas no deaths occurred in the other two groups of rats at this dose of aminopyrine. Single deaths also occurred in the 158 and $126 \mathrm{mg} / \mathrm{kg}$ aminopyrine groups when the animals were previously dosed with SKF-525-A.

Animals dying from aminopyrine succumbed within a relatively short period of time. Death was usually preceded by convulsive seizures. Hematocrits, determined on all animals in the 2000,2500 , and $4500 \mathrm{mg} / \mathrm{kg}$ dose groups, were not significantly different from each other, suggesting that hemoconcentration did not play a major role in the mortality differences noted between fed and fasted rats. 
Over the short period of time utilized in the present studies, the amount of the metabolite, 4-aminoantipyrine, found in the serum was not sufficient to allow for accurate determinations; thus only data on aminopyrine are included in this report.

TABLE 1

Acute Oral Toxicity of Aminopyrine in Fed and Fasted Rats

\begin{tabular}{|c|c|c|c|c|}
\hline \multirow[b]{2}{*}{$\begin{array}{c}\text { Dose } \\
(\mathrm{mg} / \mathrm{kg})\end{array}$} & \multicolumn{2}{|c|}{ Fed } & \multicolumn{2}{|c|}{ Fasted } \\
\hline & Dead/total & $\begin{array}{c}\text { Av. time } \\
\text { to death (min) }\end{array}$ & Dead/total & $\begin{array}{c}\text { Av. time } \\
\text { to death (min) }\end{array}$ \\
\hline 420 & $0 / 10$ & - & $0 / 10$ & - \\
\hline 840 & $0 / 10$ & - & $0 / 10$ & 一 \\
\hline 1400 & 一 & - & $4 / 10$ & 30 \\
\hline 1680 & $0 / 10$ & - & $4 / 10$ & 35 \\
\hline 1750 & - & - & $8 / 10$ & 25 \\
\hline 2000 & $1 / 10$ & 3 & $10 / 10$ & 23 \\
\hline 2500 & $1 / 10$ & 15 & $10 / 10$ & $14-15$ \\
\hline 3300 & $7 / 10$ & 18 & $9 / 10$ & 15 \\
\hline 4500 & $9 / 10$ & 13 & $10 / 10$ & 9 \\
\hline 6720 & $10 / 10$ & 5 & $10 / 10$ & 5 \\
\hline LD50 (mg/kg) & \multicolumn{2}{|c|}{$3044(2641-3508)$} & \multicolumn{2}{|c|}{$1576(1252-1984)$} \\
\hline
\end{tabular}

TABLE 2

ACUTE INTRAPERITONEAL TOXICITY OF AMINOPYRINE IN FED, FASTED, AND SKF-525-A TREATED RATS

\begin{tabular}{|c|c|c|c|c|c|c|}
\hline \multirow[b]{2}{*}{$\begin{array}{c}\text { Dose } \\
(\mathrm{mg} / \mathrm{kg})\end{array}$} & \multicolumn{2}{|c|}{ Fed } & \multicolumn{2}{|c|}{ Fasted } & \multicolumn{2}{|c|}{$\begin{array}{l}\text { Fed + SKF-525-A } \\
\quad(75 \mathrm{mg} / \mathrm{kg} \mathrm{ip})\end{array}$} \\
\hline & Dead/total & $\begin{array}{l}\text { Av. time } \\
\text { to death } \\
\text { (min) }\end{array}$ & Dead/total & $\begin{array}{l}\text { Av. time } \\
\text { to death } \\
\text { (min) }\end{array}$ & Dead/total & $\begin{array}{l}\text { Av. time } \\
\text { to death } \\
\text { (min) }\end{array}$ \\
\hline 126 & - & - & - & - & $1 / 10$ & 9 \\
\hline 158 & $0 / 10$ & - & $0 / 10$ & - & $1 / 10$ & 65 \\
\hline 200 & $0 / 10$ & - & $0 / 10$ & - & $7 / 10$ & 15 \\
\hline 225 & $0 / 10$ & - & $1 / 10$ & 15 & $8 / 10$ & 14 \\
\hline 250 & $5 / 10$ & 19 & $5 / 10$ & 10 & $7 / 10$ & 16 \\
\hline 275 & $8 / 10$ & 13 & $2 / 10$ & 14 & $8 / 10$ & 14 \\
\hline 300 & - & - & $9 / 10$ & 13 & - & - \\
\hline 316 & $10 / 10$ & 10 & $10 / 10$ & 7 & $10 / 10$ & 7 \\
\hline 398 & $2 / 2$ & 7 & $2 / 2$ & 6 & $2 / 2$ & 5 \\
\hline $\begin{array}{l}\text { LD50 } \\
\text { mg/kg }\end{array}$ & \multicolumn{2}{|c|}{$251(233-270)$} & \multicolumn{2}{|c|}{$269(247-293)$} & \multicolumn{2}{|c|}{$186(162-214)$} \\
\hline
\end{tabular}

The serum aminopyrine concentrations in the three groups of rats showed distinctly different patterns after the oral ingestion of aminopyrine, $200 \mathrm{mg} / \mathrm{kg}$ body weight 
(Fig. 1). In the fasted rat, absorption was remarkably rapid, and serum concentrations apparently reached the peak within $5 \mathrm{~min}$ after dosing. The serum concentrations dropped rather rapidly for a short time, then more slowly over the subsequent 45-min period. In rather sharp contrast was the more gradual increase in serum aminopyrine in fed rats, a much lower peak being reached after about $15 \mathrm{~min}$. In fed rats pretreated with SKF-525-A, serum aminopyrine levels increased somewhat more rapidly than in the fed animals. In all groups of animals there was little change in serum concentrations during the 30- to 60 -min time period.

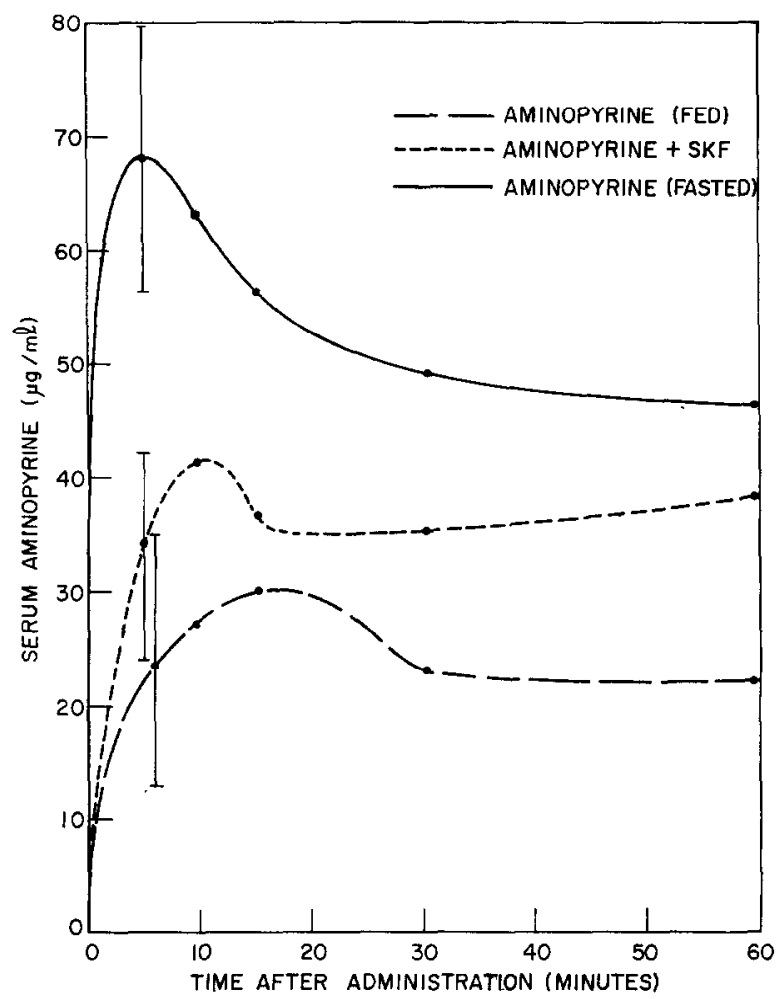

FIG. 1. Serum aminopyrine concentrations in fed, fasted, and SKF-525-A treated rats. Each animal was given an oral dose of $200 \mathrm{mg}$ of aminopyrine per kilogram of body weight at zero time. SKF-525-A was given ip ( $75 \mathrm{mg} / \mathrm{kg}) 45 \mathrm{~min}$ before dosing with aminopyrine. The bar indicates one standard error.

\section{DISCUSSION}

The acute oral LD50 data obtained for aminopyrine in fed and fasted rats were markedly different. This suggested either a considerable difference in the rate of absorption, or perhaps an altered rate or pathway of metabolism in the fasted animal. In contrast to the oral LD50 data, which indicated greater toxicity of aminopyrine in the fasted animal, the acute ip toxicity for fed, fasted, and SKF-525-A treated animals was quite comparable. Thus it appeared that the differences in acute oral LD50 between fed and fasted rats were related to rates of absorption. 
The serum aminopyrine concentrations in the three groups of rats given oral doses of $200 \mathrm{mg} / \mathrm{kg}$ of aminopyrine confirm this fact rather dramatically. Gastrointestinal absorption of aminopyrine in the fasted rat was remarkably rapid, resulting in maximal blood levels within 5 min after dosing, when the first measurements were made. In contrast, a much lower peak serum level was reached approximately 15 min after ingestion in the fed rats. Such marked differences in absorption rates and subsequent serum concentrations could readily account for the much greater oral toxicity in the fasted rat. This finding emphasizes the contention of Shannon (1947), Brodie and Reid (1967), and others that plasma concentration rather than dosage is the critical factor in determining the efficacy of drugs. The same statement, of course, relates to the toxic response to chemical compounds. It is quite apparent, from the aminopyrine values, that the greater acute oral toxicity of aminopyrine in the fasted rat relates directly to its more rapid rate of absorption. Such findings also have a significant impact upon toxicity testing procedures and may, at least partially, account for some interlaboratory variations in acute toxicity data. Although pretest treatment of animals may vary from one laboratory to another, it is important that the nutritional status of the animal be precisely stated.

The rather rapid drop from peak serum aminopyrine concentrations in the fasted rat probably represents the period of redistribution of the high serum levels into the tissues. This is then followed by a rather slow rate of decrease, representing a balance between metabolism and excretion and the readjustment of blood: tissue ratios. The mean serum aminopyrine concentrations in the SKF-525-A treated rats were somewhat higher than those of the fed animals after oral ingestion although there was considerable overlap in the data on these two groups. The present findings suggest that the pharmacologic action of aminopyrine may be prolonged in SKF-525-A treated animals. Aminopyrine is converted by $\mathrm{N}$-demethylation to 4-aminoantipyrine and then is further converted to $\mathrm{N}$-acetyl-4-aminoantipyrine, the latter two being the major excretory products. The inhibitory effect of SKF-525-A on aminopyrine metabolism has been previously documented in dogs by Axelrod et al. (1954) and in vitro in rabbit liver by Cooper et al. (1954).

\section{ACKNOWLEDGMENT}

The technical assistance of Mark Singer is gratefully acknowledged.

\section{REFERENCES}

Axelrod, J., Reichenthal, and Brodie, B. B. (1954). Mechanism of the potentiating action of $\beta$-diethylaminoethyl diphenylpropylacetate. J. Pharmacol. Exptl. Therap. 112, 49-54.

Banerjee, N. C., Miller, G. E., and Stowe, C. M. (1967). Metabolism and excretion of aminopyrine by cows. Toxicol. Appl. Pharmacol. 10, 596-603.

BerKson, J. (1944). Application of the logistic function to bio-assay. Am. Statist. Assoc. J. 39, 357.

Brodie, B. B., and Axelrod, J. (1950). The fate of aminopyrine (Pyramidon) in man and methods of estimation of aminopyrine and its metabolites in biological materials. J. Pharmacol. Exptl. Therap. 99, 171.

BRODIE, B. B., and REID, W. (1967). Some pharmacological consequences of species variation in rates of metabolism. Federation Proc. 26, 1062-1070.

COOPER, J., AXELroD, J., and Brodie, B. B. (1954), Inhibitory effects of $\beta$-diethylaminoethyl diphenylpropylacetate on a variety of drug metabolic pathways in vitro. J. Pharmacol. Exptl. Therap. 112, 55-63. 
CORNISH, H. H., and RYAN, R. (1965). Metabolism of benzene in nonfasted, fasted, and arylhydroxylase inhibited rats. Toxicol. Appl. Pharmacol. 7, 767-771.

Dixon, R., Shultice, R., and Fouts, J. (1960). Factors affecting drug metabolism by liver microsomes. Proc. Soc. Exptl. Biol. Med., 103, 333-335.

RoTH, J. S., and Bukovsky, J. (1961). Studies on an N-demethylating system in rat liver microsomes. J. Pharmacol. Exptl. Therap. 131, 275-281.

Shannon, J. A. (1947). The study of antimalarials and antimalarial activity in the human malarias. Harvey Lectures Ser. 42, 43. 